ISSN : 1978-4333, Vol. 03, No. 03

\title{
Efektivitas Iklan Politik Humas Departemen Pertanian: \\ Politik Pencitraan atau Pembentukan Ruang Publik ?
}

Sarwititi Sarwoprasodjo

\begin{abstract}
The objective of this article is to show how political advertisement as published by public relation activities has a deep effect on the change of farmers' welfare image. The study was carried out to see how far the message contained in political advertisement been in contradictive with farmers' public opinion. The contradiction normally appeared due to the ways the message was packaged. Normally the message was felt to be very plain as they were built by government and political interest, and bureaucratic flavors. Meanwhile public opinion was normally built in the fortitude of criticizing the government. Public opinion was also influenced by social status, gender, as well as social and political economic context as normally faced by their day to day life. Theoretical implication of this study is, that political advertisement concept needs to integrate participatory development communication. Some practical implication of the study showed that public relation activity needs to integrate development communication concept as well as good governance principles as they became most important Indonesian Government political jargons. Methodologically, this research has an important implication on how to measure government pubic relation effectiveness under good governance framework.
\end{abstract}

Keywords: political advertisement, public relation, political communication, public communication

\section{Latar Belakang}

Dalam era perkembangan media massa, kampanye komunikasi melalui media massa yang biasanya disebut program sosialisasi yang diselenggarakan oleh bagian humas lembaga pemerintah dianggap sebagai cara yang paling ampuh untuk menanamkan citra kinerja pemerintah di mata publik, tidak terkecuali Departemen Pertanian. Melalui program sosialisasi Biro Humas Departemen Pertanian mensosialisasikan kebijakan-kebijakan dan program-program pembangunan pertanian selama kepemimpinan Menteri Pertanian Anton Apriyantono.

Secara implisit atau eksplisit, program sosialisasi humas pemerintah mempunyai tujuan persuasif yakni merubah opini publik melalui strategi periklanan politik. Tidak dipungkiri sebagian besar kritik terhadap strategi ini adalah kecenderungan sifat manipulatif pendekatannya. Iklan-iklan politik dikritik karena lebih menekankan pada citra dan issue-issue yang dangkal dan oleh karenanya merusak landasan demokratis dalam yang lebih menekankan pentingnya issue-issue kepentingan publik (Habermas,1989), i.e., pengambilan keputusan hendaknya rasional terhadap issue kebijakan bukan kepada citra atau kepribadian figur 
pemimpin (Berelson 1966). Namun demikian, studi mengenai isi iklan politik, khususnya yang ditayangkan pada televisi, menyiratkan bahwa tuduhan tersebut tidak berdasar, karena isi iklan politik sebagian besar didasarkan pada issue (Kaid 2004; Kaid and Johnston 2001). Kritik-kritik tersebut juga relevan diajukan pada program sosialisasi yang menggunakan pendekatan periklanan.

Walaupun peran humas pemerintah semakin besar dan semakin besar juga tuntutan terhadap pemerintah untuk menerapkan tata kelola yang baik (good governance), tetapi belum banyak penelitian yang mengungkapkan pentingnya kehumasan dalam kerangka tata kelola yang baik (good governance), bahkan dalam hal pentingnya komunikasi pemerintahan (Garnett, 1992; Garnett \& Kouzmin, 1997; Graber, 2003; Horsley \& Barker, 2002) seperti dikutip Liu dan Horsley (2007). Juga secara spesifik belum banyak penelitian yang mengungkap penggunaan ukuran efektifiktivitas materi komunikasi yang dapat mengakomodasi demokratisasi. Pengukuran yang ada lebih banyak mempermasalahkan metode pengumpulan datanya (Ridout, 2004; Shen, 2007). Walaupun demikian, beberapa penulis telah melihat pentingnya memadukan konsep kehumasan dengan komunikasi pembangunan (Liu dkk, 2007; Pētersone, 2007).

Dalam artikeI ini, penulis mengawali dengan tinjauan literatur terhadap konsep opini publik dalam periklanan politik dan dalam demokrasi diskusif atau demokrasi deliberasi (ruang publik) dan faktor-faktor yang membentuknya, perumusan masalah penelitian, metodologi, temuan dan implikasi praktis, teoritis dan metodologisnya.

\section{Opini Publik sebagai Efek Iklan Politik}

Program sosialisasi Humas dapat dilihat sebagai fenomena komunikasi politik yakni komunikasi antara pembuat kebijakan (pemerintah) dengan publik, sehingga dapat dikaitkan antara kebijakan pemerintah dan opini publik. Bentuk-bentuk komunikasi politik antara dengan publik antara lain dijalin melalui program-program sosialisasi melalui badan Humas pemerintah. Sebagai bentuk periklanan politik pesan-pesan di dalam program sosialisasi itu dapat dikemas dengan berbasis pencitraan dan atau berbasis issue. Sebagai iklan politik, efektivitas program sosialisasi tersebut dapat diukur dari sejauh mana materi komunikasi keterdedahan (exposure) yakni sejauh mana publik membaca, menonton, atau mendengarkan materi komunikasi. Daya tatrik (attraction) materi komunikasi adalah kemampuan materi atau pesan (dalam bentuk simbol-simbol gambar, kata-kata, tulisan dan suara) untuk menarik perhatian responden. Pemahaman (comprehension) terhadap materi komunikasi adalah kejelasan materi komunikasi untuk dimengerti responden. Penerimaan (acceptability) terhadap materi komunikasi adalah penilaian responden terhadap isi pesan sejauhmana isinya mengandung hal-hal yang tidak sesuai dengan kenyataan, keliru, menyinggung persaan dan lain-lain. Pelibatan diri (self involvement) dari materi komunikasi adalah persepsi responden terhadap isis pesan sejauh mana ditujukan kepada dirinya dan bukan orang lain. Persuasi (persuasion) dari materi komunikasi adalah penilaian responden sejauh mana pesan tersebut meyakinkan responden untuk melakukan tindakan sesuai dengan yang diinginkan oleh pesan tersebut

Dengan perkataan lain, suatu iklan dikatakan efektif apabila pesannya telah menerpa publik, menarik, menimbulkan pemahaman, melibatkan diri publik, diterima 
sehingga publik mengenal kebijakan, program dan figur aparatur pemerintahan dalam suatu lembaga pemerintahan.

Menurut Nimmo (1997), opini publik adalah tanggapan aktif terhadap rangsangan , tanggapan yang disusun melalui interpretasi personal yang diturunkan dan turut membentuk citra. Opini mempunyai isi (opini tentang sesuatu), arah (percaya- tidak percaya, mendukung-menentang, dsb) dan intensitas (kuat, sedang atau lemah). Opini publik mempunyai ciri pluralis. Opini publik adalah pengungkapan kolektif dari kepercayaan, nilai dan pengaharapan personal yang tampil melalui saling pengaruh dari ketiga manifestasi opini publik yang beragam. Opini publik adalah gejala bersegi banyak yang disusun melalui saling pengaruh di antara proses personal, proses sosial dan proses politik.

Dalam mempersepsi suatu materi sosialisasi, publik bersifat selektif karena publik dibatasi oleh filter fisiologis (daya ingat) dan filter psikologis (motivasi menggunakan media massa, harapan terhadap lembaga pemerintahan sebagai sumber informasi dan pemecah masalah pembangunan). Selain itu, persepsi tersebut dipengaruhi oleh konteks (kehidupan sehari-hari sebagai petani, akses media informasi pertanian, budaya politik, sosial, budaya maupun kondisi perekonomian).

Opini publik tersebut sekaligus mencerminkan budaya politik yang membentuknya yakni berkenaan dengan pola kecenderungan kepercayaan, nilai dan pengharapan yang dianut publik dan aktor-aktor politik lainnya (Nimmo, 1997). Budaya politik menyangkut konsepsi autoritas yakni tentang bagaimana sebaiknya pemerintahan dilaksanakan dan mengenai konsepsi tujuan apa yang seharusnya dilakukan oleh pemerintah menurut publik.

Dari sisi pembuat kebijakan, isi opini yang penting adalah tentang kebijakan produk politik mereka. Penjabaran dan pengoperasionalan lebih lanjut dari kebijakankebijakan tersebut adalah program-program. Pertanyaan penting mereka adalah apakah publik menyetujui atau menolak kebijakan yang mereka buat? Dari informasi tersebut dapat ditafsirkan apakah pembuat kebijakan sebagai wakil sudah memenuhi harapan publiknya. Dengan dasar pengetahuan tersebut pembuat kebijakan dapat mengembangkan interaksi simbolik dengan cara membentuk hubungan dengan orang-orang (publik) yang diwakilinya maupun makna hubungan itu melalui komunikasi politik (program-program sosialisasi).

Isi penting opini publik lainnya adalah citra Menteri sebagai wakil Departemen Pertanian sekaligus wakil rakyat (petani dan stakeholder lain yang mempunyai kepentingan dengan pembangunan pertanian) melalui interaksi simbolik antara seorang wakil (representasi) dengan orang-orang yang diwakilinya maupun makna bagi hubungan itu melalui pencitraan. Publik menilai wakilnya melalui sifat-sifat wakilnya sebagai pemimpin (Menteri), pengalaman dan latar belakangnya dalam pemerintahan, pengalaman dan kualifikasinya, catatan dan asosiasi dalam politik partisan dan atribut lain yang berurusan dengan tugas sebagai menteri yang mendorong pembangunan pertanian. Di pihak lain, masyarakat menilai gaya politik Menteri. Dimensi ini berisi atribut-atribut pribadi yang dipersepsi publik (kejujuran, intelegensia, penampilan fisik dan lain-lain) dan ketrampilan sebagai aktor drama (bagaimana ia tampak dalam penampilan pribadi, penampilan di televisi dan debat). 
Mereka yang dipilih memenuhi persyaratan, yang mampu, partisipan, konsisten, dan bertindak sesuai keinginan rakyat.

Untuk mengetahui opini publik, pembuat kebijakan dapat menggunakan berbagai sumber yakni (1) ungkapan populer dari banyak warga negara (2) ungkapan simbolik dari massa atau satu atau sekelompok warga negara (3) ungkapan terorganisasi dan tak terorganisasi dari sejumlah kepentingan khusus (Nimmo, 1997).

\section{Opini Publik sebagai Ruang Publik atau Demokrasi Diskursif}

Dalam berbagai tulisan ahli komunikasi pembangunan (Servaes, 1999; White, 2004) ataupun komunikasi politik, konsep ruang publik (Habermas, 1997) banyak digunakan untuk menilai sejauhmana tindakan komunikasi menggunakan prinsip demokrasi. Konsep ruang publik ini sejalan dengan konsep-konsep lainnya seperti public deliberation, discursive democracy, deliberative democracy .

Burkhalter dkk. (2002) telah menunjukkan, deliberasi (musyawarah) didefiniskan sebagai wacana publik, dialog, dan pembicaraan yang menggunakan akal (Guttman and Thompson, 1996; Benhabib, 1996; Cohen, 1989; Dryzek, 1990; Fishkin, 1991; Bohman, 1996; Habermas, 1989) sebagai lawan dari musyawarah intrapersonal pribadi (Goodin, 2000). Ryfe (2002) berpendapat deliberasi yang bagus adalah "pengajuan klaim-klaim, penyajian bukti, pertimbangan terhadap data yang bertentangan dengan fakta." Sejalan dengan pandangan Habermas' mengenai ruang publik yang berpendapat bahwa pembicaraan deliberatif seharusnya bersifat inklusi (terbuka untuk umum), menempatkan partisipan setara, dan melakukan debat kritis rasional. Yang terpenting adalah tentang gagasan pemberian alasan, pemberian bukti, dan pemberian argumen untuk memberikan pendapat.

Istilah "demokrasi deliberatif" dan "demokrasi diskursif" sama. Namun Dryzek lebih senang menggunakan demokrasi deliberatif karena demokrasi diskursif atau "discursive democracy" menunjukkan bahwa pengambilan keputusan merupakan proses kolektif yang harus melibatkan komunikasi. Sebaliknya, deliberasi dapat dilakukan sebagai proses pengambilan keputusan secara pribadi tanpa berkomunikasi dengan orang lain. Kedua, deliberasi berkonotasi argumen yang rasional dan tenang, sedangkan proses diskursif memungkinkan beragam bentuk komunikasi, termasuk suara kelompok pinggiran yang bisa jadi tidak mengikutiaturan deliberatif. Ketiga, demokrasi diskursif dipilih karena wacana dalam pengertian Habermasian memliki konotasi kebebasan dalam mengajukan dan menentang argumen. Sebagai akibatnya, pertarungan lintas wacana dalam ruang publik menjadi kunci penting dalam demokrasi.

Deliberasi demokratis adalah bentuk komunikasi yang didasarkan pada prinsipprinsip demokrasi, Dahl (1989). Ini bersifat ideal (Gastil, 2000). Konsepsi tradisional deliberasi menekankan kesamaan, keadilan, analisis gagasan dan berfokus pada barang publik (public good) (cf., Cohen, 1996, 1997; Habermas, 1989), dan para ahli menekankan pentingnya aspek sosial deliberasi (Asen, 1996; Bohman, 1995; Burkhalter, Gastil, \& Kelshaw, 2002; Gutmann \& Thompson, 1996; Pearce \& Littlejohn, 1997).

Beberapa ahli komunikasi politik pada umumnya membatasi deliberasi hanya pada konteks khusus, seperti sekelompok kecil warga yang berkumpul mendikusikan 
issu-issu umum. Namun demikian, banyak ahli komunikasi massa berpendapat bahwa konsep ruang publik dapat diperlakukan sebagai konsep umum yang menyatukan beragam penelitian komunikasi.

Dalam komunikasi yang di mediasi oleh media massa, Gastil dan Laura (2007) mengajukan bahwa konsep deliberasi dapat menunjukkan proses analitik dan proses sosial sekaligus (Matriks 1)

Matriks 1. Karakteristik Deliberasi yang melalui Media

\begin{tabular}{|c|c|c|}
\hline $\begin{array}{c}\text { Proses } \\
\text { analitik }\end{array}$ & Fungsi sistem media & Perilaku pengguna media \\
\hline $\begin{array}{l}\text { Menciptakan } \\
\text { dasar } \\
\text { informasi }\end{array}$ & $\begin{array}{l}\text { Menyajikan informasi dasar dengan } \\
\text { melaporkan secara luas issue-issue } \\
\text { penting. }\end{array}$ & $\begin{array}{l}\text { Mencari kesempatan untuk belajar } \\
\text { pengalaman orang lain dan analisis } \\
\text { ahli. }\end{array}$ \\
\hline $\begin{array}{l}\text { Memprioritas } \\
\text { kan nilai-nilai } \\
\text { kunci }\end{array}$ & $\begin{array}{l}\text { Mengeksplor apa yang menjadi } \\
\text { latarbelakang dibalik fakta-fakta } \\
\text { dan kejadian-kejadian di } \\
\text { permukaan. }\end{array}$ & $\begin{array}{l}\text { Mempertimbangkan beragam latar } \\
\text { belakang mengapa orang punya } \\
\text { kepedulian dan bagaimana orang lain } \\
\text { memprioritaskan }\end{array}$ \\
\hline $\begin{array}{l}\text { Mengidentifik } \\
\text { asi solusi }\end{array}$ & $\begin{array}{l}\text { Menyampaikan beragam solusi, } \\
\text { termasuk solusi di luar pemerintah } \\
\text { dan yang tidak popular. }\end{array}$ & $\begin{array}{l}\text { Mempelajari bagaimana orang suka } \\
\text { atau tidak suka terhadap cara orang } \\
\text { lain mengatasi masalah. }\end{array}$ \\
\hline $\begin{array}{l}\text { Memberi } \\
\text { bobot solusi }\end{array}$ & $\begin{array}{l}\text { Melaporkan beragam pandangan } \\
\text { yang berbeda tidak sekedar } \\
\text { menyajikan tetapi juga meneliti } \\
\text { secara lebih baik }\end{array}$ & $\begin{array}{l}\text { Menilai bias-bias diri sendiri } \\
\text { terhadap solusi yang berbeda dengan } \\
\text { melihat orang yang pro atau kontra. }\end{array}$ \\
\hline $\begin{array}{l}\text { Membuat } \\
\text { keputusan } \\
\text { terbaik }\end{array}$ & $\begin{array}{l}\text { Memberi rekomendasi tetapi } \\
\text { menjaga isi editorial berbeda dari } \\
\text { berita, membiarkan pembaca } \\
\text { mengambil keputusan. }\end{array}$ & $\begin{array}{l}\text { Memperbaiki pandangan setelah } \\
\text { memperoleh informasi dari ahli, } \\
\text { partisan dan lain-lain. }\end{array}$ \\
\hline Proses sosial & Fungsi sistem media & Perilaku khalayak \\
\hline $\begin{array}{l}\text { Kesempatan } \\
\text { berbicara }\end{array}$ & $\begin{array}{l}\text { Menggunakan beragam sumber dan } \\
\text { mencapai debat yang konvensional. }\end{array}$ & $\begin{array}{l}\text { Mendengarkan pandangan yang } \\
\text { berbeda. Kalau perlu menambahkan } \\
\text { suara sendiri. }\end{array}$ \\
\hline $\begin{array}{l}\text { Pemahaman } \\
\text { bersama }\end{array}$ & $\begin{array}{l}\text { Membuat berita dan informasi } \\
\text { dapat dipahami untuk khalayak. }\end{array}$ & $\begin{array}{l}\text { Mencari klarifikasi terhadap issue } \\
\text { atau argumen yang membingungkan. }\end{array}$ \\
\hline Pertimbangan & $\begin{array}{l}\text { Mempertimbangkam setiap } \\
\text { argumen dari berbagai perspektif. }\end{array}$ & $\begin{array}{l}\text { Ketika mendengarkan beragam } \\
\text { pandangan, menghindari langsung } \\
\text { menjawab dengan argumen sebelum } \\
\text { mempertimbangkan apa yang } \\
\text { dikatakan }\end{array}$ \\
\hline Penghormatan & $\begin{array}{l}\text { Menghormati beragam pandangan; } \\
\text { memperlakukan khalayak dengan } \\
\text { membuat berita yang serius. }\end{array}$ & $\begin{array}{l}\text { Mengambil manfaat terhadap } \\
\text { keraguan terhadap sumber dan } \\
\text { menuntut diri sendiri mampu } \\
\text { menunjukkan perilaku lebih baik } \\
\text { terhadap orang yang meragukan } \\
\text { kepercayaan kita. }\end{array}$ \\
\hline
\end{tabular}


Saat ini bidang komunikasi pembangunan didominasi oleh dua pendekatan yakni model : Difusi Inovasi yang lebih menyerupakan sdtarategi periklanan dan Komunikasi Partisipatori yang lebih dekat dengan konsep ruang publik. Difusi inovasi dipandang sebagai transmisi informasi dari sumber ke penerima. Tujuan komunikasi adalah meningkatkan pengetahuan, melakukan persuasi, dan perubahan perilaku. Empat kelemahan pendekatan diffusi adalah lemahnya pemahaman konteks budaya, bias media, pro-persuasi dan fokus pada inovasi, dan kurangnya pembahasan mengenai kekuasaan.

Pendekatan partisipatori berfokus pada pemberdayaan masyarakat lokal dalam memenuhi kebutuhan pembangunannya. Kelemahan utama pendekatan ini: kegagalan untuk menjelaskan cara-cara komunitas lokal menjadi siap berubah, berfokus pada niali-nilai Barat akan kesamaan dan partisipasi, ketiadaan ukuran untuk mengevaluasi keberhasilan komunikasi partisipatori, dan kurangnya penjelasan di tingkat perilaku partisipatori.

Selain kelemahan, kedua pendekatan memiliki unsur-unsur yang penting untuk pembangunan. Oleh karena itu Pētersone (2007) mengusulkan pendekatan baru yang mengintegrasikan dua perspektif. Empat dimensi humas- asimetris-simetris, komunikasi satu arah-komunikasi dua arah, komunikasi melalui media massa vs interpersonal, dan etika - memberikan dasar yang kuat untuk pendekatan terpadu komunikasi pembangunan. Pendekatan ini perlu diterapkan pada situasi pembangunan setelah di analisis unsur-unsur kontekstual, termasuk sistem politik, tingkat pembangunan ekonomi dan tingkat aktivism, kebudayaan dan sistem media.

\section{Perumusan masalah}

Berdasarkan tinjauan pustaka tersebut menjadi relevan untuk mengajukan pertanyaan penelitian sejauh mana program sosialiasi Humas sebagai iklan politik berhasil menanamkan citra positif kinerja Departemen Pertanian berupa keberhasilan meningkatkan kesejahteraan petani ? Apakah pesan iklan politik tersebut berhasil menanamkan citra kebanggaan sebagai petani atau sebaliknya menimbulkan keprihatinan bagi publik? Apa faktor-faktor yang membentuk opini publik mengenai kesejahteraan petani? Juga dapat diketahui sejauh mana program tersebut membentuk opini publik mengenai citra Menteri sebagai representasi Departemen Pertanian (sebagai pemimpin dalam menjalankan tugas dan citra pribadi)?

\section{Metode Penelitian}

Penelitian ini merupakan penelitian evaluasi terhadap materi komunikasi Program Sosialisasi Biro Hukum dan Humas Departemen Pertanianm yang dipublikasikan pada bulan Juli - November 2008. Dalam program tersebut terdapat sembilan paket program sosialisasi melalui media massa dengan beragam format media cetak (advetorial, Iklan Layanan Masyarakat/ILM dan feature), media radio (sandiwara, jingle/lagu, ILM) dan televisi (sinetron, variety show, ILM, dan film dokumenter) serta event (lomba menulis). Lokasi penelitian ditentukan secara purposif yakni Lampung (Lampung Tengah dan Lampung Selatan), Jawa Barat (Cianjur dan Karawang), Jawa Tengah (Klaten dan Sragen), Jawa Timur (Malang dan Lamongan), Sulsel (Sidrap dan Maros) dan NTB ( Sumbawa dan Lombok Tengah). Penelitian di dahului dengan survei terhadap 1200 responden mewakili petani, 
pengusaha pertanian, dan masyarakat umum untuk mengetahui perilaku komunikasi dan keterdedahannya akan materi komunikasi Program Sosialisasi. Selanjutnya dilakukan FGD dengan 5-10 partisipan (di Jakarta dan di Lampung, Jawa tengah, Jawa Timur, NTB, dan Sulawaesi Selatan). Partisipan FGD/wawancara kelompok adalah akademisi, politisi dan wartawan di Jakarta dan petani (laki-laki dan perempuan), petani anggota kelompok tani, tokoh masyarakat, dan PPL/Dinas Pertanian.

Desain evaluasi dengan cara eksperimen post test only yakni dengan menunjukkan materi komunikasi kepada partisipan FGD. Setelah itu, mereka ditanya untuk mengetahui tanggapan mereka terhadap materi komunikasi untuk mengukur efektivitas materi komunikasi. Materi sosialisasi yang diuji adalah Sinetron Kaidah Cinta (episode 5) di TPI, ILM "Terimakasih Petani" di TPI, Lagu "Swasembada Pangan", "Jayalah Petani", ILM " "Penganekaragaman Makanan Pokok", "Penggunaan Pupuk Organik dan Pupuk Berimbang", "Penyelamatan Hasil Panen" di stasiun radio tertentu dan advetorial "Pancayasa Pembangunan Pertanian", "Dua Mentan Panen Kapas dan Jagung di Sulsel", "Bank dan Petani Sama-sama Untung" serta ILM "Diversifikasi Pangan Memperkuat Ketahanan Pangan Kita", "Mari, Selamatkan Hasil Panen Kita", "Konversi Lahan Ayo Kita Cegah rame-Rame" di media cetak (beberapa koran tertentu dan buletin Sinar Tani).

\section{Temuan Penelitian \\ Konteks Sosial, Ekokomi dan Politik Iklan Politik}

Temuan penelitian ini tidak terlepas dari konteks sosial dan politik yang terjadi di Indonesia pada saat penelitian, khususnya yang terkait dengan issue-issue pembangunan pertanian. Pertama, program sosialisasi diselenggarakan pada akhir masa kerja kabinet 2005-2009, berbarengan dengan berbagai iklan layanan masyarakat yang dikeluarkan oleh berbagai badan humas Departemen atau Kementrian untuk melaporkan kemajuan pembangunan. Dalam waktu yang bersamaan merupakan masa kampanye pemilihan legilislatif dan presiden sehingga berbagai partai-partai politik besar (PDIP, PAN, Golkar, gencar melancarkan kampanye iklan politiknya melalui media (televisi) dengan mengangkat issue-issue pertanian dan kesejahteraan petani.

Kedua, di tingkat petani, pada bulan Juli - November 2008 (saat terjadinya program sosialisasi Humas) mengalami kelangkaan pupuk, harga jual padi turun, daya beli petani dan konsumen pangan semakin menurun.

Berbagai tuntutan kepada pemerintah diajukan oleh LSM antara lain :

1. Mematok harga dasar pangan yang menguntungkan petani dan konsumen. Harga tidak boleh tergantung kepada harga internasional karena tidak berkorelasi langsung dengan ongkos produksi dan keuntungan. Harga harus sesuai dengan ongkos produksi dan keuntungan petani dan kemampuan konsumen

2. Memberikan insentif harga kepada petani komoditas pangan (terutama beras, kedelai, jagung, singkong, gula dan minyak goreng) jika terjadi fluktuasi harga. Hal ini sebagai jaminan untuk tetap menggairahkan produksi pangan dalam negeri. 
3. Mengatur kembali tata niaga pangan. Pangan harus dikuasai oleh negara dan digunakan sebesar-besarnya untuk kemakmuran rakyat. Bulog bisa diberikan peran ini, tapi harus dengan intervensi yang kuat dari Departemen Pertanian, Departemen Perdagangan dan Departemen Keuangan.

4. Menambah produksi pangan secara terproyeksi dan berkesinambungan, dengan segera meredistribusikan tanah objek landreform yang bisa segera dipakai untuk pertanian pangan.

5. Menyediakan insentif bagi petani komoditas pangan, terutama bibit, pupuk, teknologi dan kepastian beli

6. Memberikan dukungan pelembagaan organisasi petani komoditas pangan, yakni kelompok tani, koperasi, dan ormas tani

7. Pembatasan impor gula

8. Pembatasan impor daging sapi

Ketiga, di tingkat kelembagaan informasi pertanian, terjadi restrukturisasi kelembagaan penyuluhan. Di beberapa tempat, PPL tidak mempunyai kewenangan dan peran yang besar dalam kegiatan penyuluhan di lapangan. Di Klaten (Jawa Tenga) Sejak Otonomi Daerah tahun 2000, Penyuluh Pertanian Lapangan di bawah naungan Balai Ketahanan Pangan dan bukanlah dibawah naungan Dinas Pertanian dan Tanaman Hortikultura. Di Kabupaten Klaten, sebelum tahun 2002 lembaga penyuluhan adalah lembaga yang otonom. Namun sejak ada SK Bupati tahun 2002/2003, lembaga penyuluhan diserahkan kepada pemerintahan Daerah, pengelolaan ini berdampak terhadap jumlah sumberdaya yang terbatas dan ini berakibat kepada intensitas pertemuan penyuluh lapangan dengan petani-petani yang tergabung di kelompok tani kelurahan yang ada. Sistem ini menyulitkan mereka untuk mengambil keputusan dalam merancang program penyuluhan.

Kondisi sekarang Lembaga penelitian dan lembaga penyuluhan bekerja sendirisendiri. Pelaksanaan RPP di Kabupaten Lampung Selatan dari fokus penataan kelembagaan penyuluhan pertanian tahun 2008 memasuki tahap pengesahan lembaga penyuluhan pertanian menjadi Badan Pelaksana Penyuluhan Pertanian dan Ketahanan Pangan. Berdasarkan Perda No.6 tahun 2008 tanggal 26 Sepember 2008, KIPP (Kantor Informasi Penyuluhan Pertanian) yang merupakan tempat bernaung PPL sejak tahun 2001, berubah menjadi Badan Pelaksana Penyuluhan Pertanian dan Ketahanan Pangan. Dengan demikian, secara struktural memiliki hubungan koordinasi dengan Dinas Pertanian, Dinas Peternakan, dan Dinas Perkebunan yang berada langsung dibawah komando Bupati Lampung Selatan.

Pelaksanaan RPP di Kabupaten Lampung Tengah dari fokus penataan kelembagaan penyuluhan pertanian tahun 2008 memasuki tahap realisasi pembentukan Badan Ketahanan Pangan dan Penyuluhan Pertanian berdasarkan Perda No.14 tahun 2007. Sebelumnya penyuluh pertanian berada dibawah naungan Balai Informasi Penyuluhan Pertanian (BIPP) dan kembali ke Dinas Petanian pada tahun 2002. Terbentuknya Badan Ketahanan Pangan dan Penyuluhan Pertanian tersebut tidak lepas dari peran para penyuluh yang menuntut agar lembaga penyuluhan bisa berdiri sendiri sesuai amanat UU No 16 tahun 2006. Terbentuknya lembaga tersebut juga merupakan wujud eksistensi para penyuluh yang sebelumnya tidak jelas dimana mereka bernaung. Kelembagaan Penyuluhan Pertanian di tingkat kecamatan pelaksanaannya melalui Balai Penyuluhan Pertanian (BPP) yang dikoordinasikan 
oleh Kepala Balai Penyuluhan Pertanian merangkap Koordinator Penyuluh Pertanian. Keberadaan BPP saat ini sangat diperlukan dan telah diadakan perbaikan serta ada penambahan pembangunan baru (9 BPP) baik melaui dana APBN dan APBD II juga ada swadaya kelompok tani (4 BPP, termasuk BPP Kecamatan Punggur).

Sedangkan Penyuluh di Kabupaten Sidrap dibawah naungan BPKP (Badan Penyuluhan dan Ketahanan Pangan) pada tahun 2008, hanya saja nama ini selalu berubah-ubah. Tahun 2005 hingga tahnun 2007 namanya BKPP (Badan Ketahanan Pangan dan Penyuluhan). Sebelum tahun 2005, Penyuluh dibawah naungan Dinas Pertanian dan Perkebunan. Di setiap kecamatan ditempatlkan penyuluh untuk bidang tugas Tanaman Pangan, peternakan, perkebuanan, dan kehutanan.

\section{Opini Publik tentang Kebijakan, Program Pembangunan Pertanian dan Figur Menteri Pertanian}

Tingkat pengenalan publik terhadap Kebijakan Departemen Pertanian dicerminkan oleh sekitar $60 \%$ mengenal kebijakan pembangunan pertanian yakni peningkatan produksi (63.5\%), kelembagaan petani (73.3\%), kebijakan tentang infrastruktur pertanian (61.9\%), serta kebijakan mengenai akses ke lembaga keuangan (58.8\%). Sedangkan dalam hal program pembangunan pertanian, mereka mengetahui Program Ketahanan Pangan (59,1\%-65,9\%), Program Pengembangan Agribisnis (61\% - 64,7\%), Program Peningkatan Kesejahteraan Petani (58,8 \% - 66, 0\%). Mereka yang mengenal kebijakan dan program pembangunan pertanian, menilai program-program tersebut baik untuk petani.

Secara umum pengenalan dan pengetahuan responden terhadap figur Menteri Pertanian Anton Apriyantono sudah cukup baik, yang ditunjukkan oleh hasil survey dimana $49.4 \%$ bisa menyebutkan dengan benar nama menteri pertanian dan $64.1 \%$ mengenal secara tepat wajah/gambar Menteri Anton Apriyantono. Citra yang dianggap melekat kuat pada sosok Menteri Pertanian Anton Apriyantono yakni merakyat dan sederhana $(30.3 \%)$, religius $(18.6 \%)$, rendah hati $(17.0 \%)$, bebas dari KKN (10.3\%) serta memiliki integritas yang kuat (8.7\%). Dalam hal kepemimpinan, publik menilai Anton Apriyantono jujur dan berani (61,5\%), integritas moral baik (80,0\%), hubungan kerja dengan LSM \& pengusaha kategorinya baik $(52,6 \%)$, pengambilan keputusan $(63,3 \%)$, dan hubungan kerja dengan lembaga pemerintah lain $(52,6 \%)$.

Informasi mengenai kebijakan dan program pembangunan pertanian selama ini mereka peroleh dari berita/informasi penyuluh pertanian $43.0 \%$, media elektronik (televisi dan radio) 38.1\%, media cetak (koran dan majalah, dll) $27.6 \%$, spanduk/baliho $0.6 \%$ dan media on-line/internet $0.6 \%$. Stasiun televisi yang menurut mereka paling banyak pesan-pesan pertanian adalah TVRI (23.8\%), RCTI (21.5\%), SCTV (20.0\%) dan Metro TV (19.8\%). Sedangkan sumber informasi mengenai figur dan kinerja Menteri Pertanian berasal dari berita/informasi televisi (42.4\%), radio $(17.2 \%)$, kunjungan menteri ke daerah $(19.2 \%)$, media cetak (koran dan majalah, dll) $(6.5 \%)$, media online internet $(2.5 \%)$, spanduk/baliho (1.5\%) dan leaflet/brosur $(0,7 \%)$. Sinartani hanya dikenal oleh sekitar $19 \%$ petani saja. Bagi responden yang memperoleh informasi pertanian dari acara televisi, mereka umumnya menonton program talk show/reality show/dialog pada jam 20.00 - 23.00 
(67.4\%). Hanya sebagian kecil yang memperoleh informasi dari program berita yang ditayangkan antara pukul $05.00-08.00(24 \%)$.

\section{Terpaan (exposure).}

Dengan mempertimbangkan ukuran efektivitas materi sosialisasi yang merupakan prasyarat untuk mencapai efektifitas yang lebih tinggi yakni terpaan (exposure) materi sosialisasi, hasil survei menunjukkan baru sekitar 5-10\% publik yang terterpa oleh materi program sosialisasi (sampai 13 Nopember 2008). Ini terkait dengan perilaku komunikasi masyarakat petani. Petani menggunakan televisi maupun radio lebih sebagai media hiburan dibandingkan sebagai media untuk mencari informasi. Di lain pihak, sumber informasi pertanian terpenting masyarakat adalah PPL dengan metode dan media penyuluhan pertanian. Bagi petani yang tidak aktif dalam kegiatan penyuluhan pertanian, mereka mendapatkan informasi dari kalangan sesama petani. Program sosialisasi Humas Deptan, belumlah cukup gencar untuk menarik perhatian publik apabi;a dibandingkan dengan iklan politik dari partai Gerindra yang banyak mengekspose Prabowo.

\section{Opini Publik tentang Kesejahteraan Petani}

Dalam rangka melaporkan kemajuan Departemen Pertanian pada akhir masa kabinet 2008/2009, pesan-pesan di dalam program sosialisasi dikemas mencitrakan kesejahteraan petani dan pelayanan pemerintah melalui program-program pembangunan pertanian. Sebagai iklan politik, efektivitas program sosialisasi tersebut dapat diukur dari sejauh mana materi komunikasi telah menerpa publik, menarik, menimbulkan pemahaman, melibatkan diri publik dan diterima, sehingga publik mengenal kebijakan, program pembangunan pertanian dan figur Menteri Pertanian, sekaligus mengakui kinerja Departemen Pertanian.

Opini publik tentang kesejahteraan petani dapat dibandingkan dengan pencitraan kesejahteraan yang dikemas dalam materi komunikasi program sosialisasi Humas Deptan yang bersifat audio visual (televisi), visual-cetak (koran) dan audio (radio). Opini tesebut beragam sesuai dengan segmen khalayak yakni antara petani perempuan dengan petani laki-laki, petani biasa dan anggota/pengurus kelompok tani, tokoh masyarakat, LSM, wartawan dan politisi. Perbedaan segmen tersebut juga mengindikasikan pada perbedaan keaktifan mereka dalam kelompok tani dan aktivitas sosial .

Terlepas dari jam tayang yang terlalu pagi (pukul 7.00) sehingga tidak ada yang menontonnya, para petani perempuan menilai bagus tayangan sinetron "Kaidah Cinta" karena latar belakang ceritanya mengenai kehidupan masyarakat desa. Permainan aktor utamanya dan ceritanya relevan dengan kehidupan mereka seharihari. Walaupun demikian, sebagian dari mereka menilai penampilan para petani perempuan dalam sinetron terlalu mewah. Mereka juga menilai visualisasi hasil panen yang melimpah dalam "ILM Terimakasih Petani" bagus.

Para petani perempuan tidak mengenali sosok Anton Apriyantono dalam ILM. Kalaupun mereka ingat terdapat spokeperson dalam ILM mereka mengira itu adalah Prabowo. Nampaknya citra Prabowo melalui iklan politiknya berhasil mengalahkan perhatian terhadap figur menteri pertanian. Para politisi, akademisi, wartawan dan PPL yang mengenal sosok Menteri dalam ILM tersebut lebih menangkap citra 
menteri sebagai wakil partainya melalui simbolisasi mengucapkan syukur (citra partai yang religius) daripada citra profesional seorang Menteri Pertanian.

Dalam hal pemahaman (comprehension), mereka memahami isinya dan menilai slogannya bagus serta mencitrakan keberhasilan pertanian (atraction). Mereka juga menyadari kalau ILM tersebut ditujukan kepada mereka (self-involvement). Namun demikian, sebagian besar publik menilai ILM tersebut tidak menimbulkan kebanggaan sebagai petani (sesuai dengan tujuan program sosialisasi), karena ILM itu tidak mencerminkan kenyataan kehidupan mereka sehari-hari yang memprihatinkan (kendala penyediaan saprodi, misalnya kelangkaan pupuk, keterbatasan kredit dan irigasi). Penilaian seperti ini terutama berasal dari segmen publik yang lebih kritis yakni anggota kelompok tani aktif, tokoh masyarakat, LSM, akademisi, wartawan dan politisi.

Sedangkan bagi petani biasa yang tidak kritis (bukan anggota kelompok tani), ILM "Terimakasih Petani" yang ada telah memberikan kebanggaan kepada mereka, karena tayangan dalam televisi yang memungkinkan ditonton secara luas mereka anggap sebagai bentuk pengakuan akan keberadaan profesi mereka.

Berbeda dengan iklan politik dalam media cetak, bagi petani biasa (bukan anggota kelompok tani ataupun anggota) dan tokoh masyarakat petani, advetorial tersebut kurang menarik, karena tulisan dan fotonya terlalu kecil, padat dan informasinya bertele-tele, tidak berwarna dan tidak ada tokoh petaninya. Oleh karena itu, petani maupun tokoh masyarakat tidak mengenali foto Menteri atau Presiden dan Wakil Presiden yang ada di advetorial tersebut

Sedangkan tanggapan terhadap jingle dan ILM melalui radio, pada umumnya mereka (seluruh segmen) menyukai. Mereka menyukai unsur-unsur artistiknya (musik, jingle, dialognya, efek khusus suara) yang membangkitkan imajinasi dunia pertanian dan pedesaan. Mereka umumnya mampu memahami isi pesannya. Walaupun demikian, khusus petani, mereka mengeluhkan ILM terlalu cepat dalam penyampaiannya, sehingga tidak mampu menangkap isinya.

\section{Implikasi Pengembangan Strategi Program Sosialisasi}

Kegiatan kehumasan dalam organisasi pemerintah mengikuti model Roda keputusan Komunikasi Pemerintah (Liu, 2008) . Dalam model ini pengambilan keputusan komunikasi pemerintah melibatkan interaksi 4 lingkungan mikro. Keempat lingkungan tersebut menyangkut Dalam keempat lingkungan mikro, government manajer pemerintah berbagi keahlian dan sumberdaya juga mengkoordinasikan komunikasi. Di dalam masing-masing lingkungan mikro, komunikator pemerintah harus memutuskan saluran dan arah komunikasi. Satu jeruji pada roda keputusan mewakili komunikasi melalui media, dan yang lainnya mewakili target publik (komunikasi langsung tanpa media). Irisan menunjukkan proporsi komunikasi melalui media dan yang bersifat langsung yang selanjutnya akan menentukan saluran yang tepat (see Figure 2). Titik-titik irisan berubah sesuai dengan situasi dan tujuan komunikasi. Garis putus-putus menunjukan permeabilitas batas-batas lingkungan mikro, dan arah aliran informasi. Dalam semua lingkungan mikro, pemerintah bisa memutuskan untuk menahan informasi dari media atau publik, atau menyebarkan informasi langsung ke media atau publik. Sebagai tambahan, 
pesan bisa berasal dari praktisi kehumasan, publik dan media, mengindikasikan potensi sifat asimetris searah dan dan dua arah yang simetris dalam sektor publik.

Departemen Pertanian secara keorganisasian mempunyai dua lembaga yang berurusan dengan komunikasi dengan rakyat yakni bagian Humas Sekjen Departemen Pertanian dan Badan Pengembangan Sumberdaya Manusia yang dikenal dengan lembaga penyuluhan. Dalam banyak hal target sasaran khalayak kedua lembaga ini mempunyai kesamaan yakni petani, walaupun secara umum keduanya menggunakan pendekatan yang berbeda. Keduanya sama-sama mewakili Departemen Pertanian dan keduanya menggunakan sumberdana dari pemerintah. Keduanya di mata rakyat adalah wakil pemerintah. Yang pertama lebih menggunakan strategi periklanan politik dan yang kedua diharapkan menjalankan fungsi pendidikan. Humas lebih berorientasi politik, penyuluhan lebih berorientasi pendidikan. Humas lebih banyak mengandalkan media massa dengan one way communication, penyuluhan menggunakan tatap muka potensial untuk two way communication. Humas lebih reaktif terhadap issue dari luar, penyuluhan lebih programatik. Humas bekerja berdasarkan prinsip kehumasan dan politik dan penyuluhan bekerja berdasarkan orientasi pendidikan. Fakta ini mempunyai dua implikasi yakni potensi sekaligus masalah. Bagaimana koordinasi dalam lingkungan internal Departemen Pertanian dalam memanfaatkan sumberdaya dan meningkatkan efektivitas (efficacy) program sosialisasi? Apakah dua pendekatan tersebut mempunyai risiko mengacaukan kepercayaan petani terhadap pemerintah.

Melihat kenyataan di lapangan bahwa sumber informasi pertanian terutama dari Penyuluh Pertanian Lapangan, maka seyogyanya Biro Hukum dan Humas Sekjen Deptan mengintegrasikan strategi sosialisasinya tidak hanya berbasis media massa, tetapi juga dengan memanfaatkan saluran interpersonal berkoordinasi dengan lembaga penyuluhan pertanian di tingkat lokal. Pendekatan yang digunakannya hendaknya lebih menekankan pada fungsi komunikasi sebagai sarana demokratisasi (pembentukan ruang publik) bukan politik pencitraan untuk kepentingan politik tertentu. Dalam kerangka pembentukan ruang publik, maka informasi yang disampaikan hendaknya memenuhi kebutuhan komunikasi stakeholder pembangunan pertanian dan menyuarakan suara beragam stakeholder pembangunan pertanian khususnya petani secara berimbang. Secara visualpun petani perlu ditampilkan di dalam materi sosialisasi. Pilihan strategi ini sejalan dengan prinsip good governance yakni prinsip partisipasi, responsiveness, akuntabilitas, dan transparansi. Dengan prinsip partisipasi, petani terlibat tidak hanya memperoleh informasi yang sesuai dengan kebutuhan petani, tetapi juga pilihan media, format ataupun pilihan simbol-simbolnya (mencitrakan petani dalam kehidupan nyata). Dengan prinsip akuntabilitas, materi sosialisasi hendaknya mampu menyajikan kronologis suatu peristiwa yang menyangkut permasalahan pembangunan pertanian dan upaya pemecahannya (misalnya mengapa terjadi kelangkaan pupuk). Sedangkan dengan prinsip transparansi, materi sosialisasi menggunakan dasar-dasar informasi yang akurat dari sumber yang kredibel. Dengan dipandu oleh kerangka demokratisasi, maka pendekatan program sosialisasi konsisten dengan pendekatan penyuluhan pertanian yang partisipatif.

Dengan mengintegrasikan program sosialisasi Humas dengan program penyuluhan pertanian, akan meningkatkan terpaan karena memalui PPL dapat dilakukan mobilisasi petani untuk menonton, mendengar dan membaca materi sosialisasi 
Humas Deptan. Bahkan PPL bisa menjadikan materi sosialisasi yang bersifat menginsiprasi misalnya keberhasilan petani di tempat lain sebagai materi dialogdialog di tingkat lokal dengan demikian akan meningkatkan partisipasi publik dalam membicarakan agenda-agenda mereka sendiri. Informasi yang disampaikan melalui materi sosialisasi hendaknya tidak tumpang tindih (redundance) dengan informasi dari PPL, sebagai contoh untuk program yang telah dikenalkan di daerah, tidak perlu disosialisasikan melalui media massa. Sebaliknya, sosialisasi yang luas melalui media massa mempunyai risiko menimbulkan kecemburuan apabila di daerah tidak ada atau belum siap merealisasikannya. Pengintegrasian ini, hendaknya tidak hanya dalam pelaksanaannya, tetapi juga dilakukan mulai dari tahap perencanaan sehingga program sosialisasi sinergis dan menjamin relevansi masalah yang diangkat dengan kebutuhan informasi (dan komunikasi) petani. Selain itu, dengan pengintegrasian tersebut efek program sosialisasi dapat diperkuat melalui pendekatan mobilisasi sosial yang digunakan dalam program penyuluhan pertanian (antara lain melalui pendekatan kelompok tani, pelibatan tokoh masyarakat sebagai pemuka pendapat). Pilihan stategi ini sejalan dengan prinsip efektivitas dan efisiensi dalam good governance. Untuk meningkatkan terpaan media tidak harus dengan cara meningkatkan intensitas publikasi, tetapi dapat dilakukan dengan memanfaatkan struktur organisasi melalui koordinasi. Humas Deptan bisa bekerjasama dengan PPL dan pemerintah tingkat desa untuk menginformasikan kepada masyarakat misalnya jam tayang atau jam siaran materi sosialisasi. Untuk meningkatkan efektivitas perlu dibarengi dengan kajian yang memadai (untuk perencanaan dan evaluasi). Untuk menjamin efisiensi juga, dalam pelaksanaannya perlu berkoordinasi dengan berbagai lembaga di tingkat Departemen Pertanian (direktorat-direktorat, lembaga penelitian dan lembaga sumberdaya manusia), baik di pusat, provinsi maupun kabupaten yang masing-masing juga menyelenggarakan kegiatan yang bersifat memberikan informasi (sosialisasi). Pilihan Metode dan Format Sosialisasi Program melalui Media Massa Sebagian besar masyarakat (semua segmen) menilai media televisi sebagai media yang potensial untuk digunakan sebagai media komunikasi, asalkan ditayangkan pada saat yang tepat yakni malam hari yang merupakan waktu luang petani. Sedangkan formatnya, beragam bisa sinetron, bincang-bincang. Bagi mereka yang terpenting adalah isinya relevan bagi kebutuhan petani dan mencerminkan kondisi sesungguhnya. Mereka berharap pemeran yang ditampilkan adalah petani atau orang-orang yang dinilai petani memang berpihak kepada mereka. Visualisasinyapun (latar belakang, rumah, baju, gaya dan gerak-geriknya) menggambarkan petani dan kehidupannya yang sesungguhnya. Para akademisi, wartawan dan politisi menyarankan untuk menjamin kredibilitas informasi, format testimony dari stakeholder pembangunan pertanian dalam materi-materi komunikasi (khususnya ILM), akan lebih meningkatkan tranparansi program sosialisasi. Selain itu, citra Menteri pertanian hendaknya lebih ditonjolkan unsur profesionalismenya daripada citra kepartaiannya. Sedangkan apabila menggunakan media cetak seperti ILM petani menganjurkan, tokoh yang ditampilkan adalah tokoh petani yang berhasil bukan artis. Untuk advetorial mereka menyarankan agar tulisan dan fotonya diperbesar dan berwarna. Sebagian menyarankan untuk membuat leaflet atau buku sehingga bisa dibaca kembali. Melalui media radio petani menyarankan pengucapan kata-kata dalam ILM tidak terlalu cepat. Media lokal juga mempunyai potensi untuk digunakan sebagai media sosialisasi kebijakan dan program Departemen 
Pertanian sesuai dengan budaya setempat, sebagai contoh untuk daerah Lampung (menggunakan musik lampung, dan berbagai kesenian dari berbagai etnik), Jawa Tengah (wayang golek, "gejlog lesung", pentas campur sari) dan Sulsel (forumforum pertemuan rutin seperti "tudang sipulang"). Penggunaan media lokal ini secara tidak langsung dapat memperkuat jati diri budaya petani.

Dari segi metodologis implikasi hasil penelitian adalah perlunya modifikasi indikator ukuran efektivitas, kredibilitas informasi sebagai basis dialog, kesesuaian dengan budaya petani dan penggunaan kemampuan menyuarakan kepentingan petani.

\section{DAFTAR PUSTAKA}

Faden, RR. 1987. Ethical Issues in Government Sponsored Public Health Campaigns. Health Education \& Behavior. 1987; 14; 27. di download di ://heb.sagepub.com/cgi/content/abstract/14/1/27

Kim, Kyun Soo., Roskos-Ewoldsen, Beverly. and Roskos-Ewoldsen, David 2007. . "Understanding the Effects of Message Frames in Political Advertisements: A Lesson From Text Comprehension" Paper presented at the annual meeting of the International Communication Association, TBA, San Francisco, CA, May 23, 2007 Online <PDF>. 2008-12-09

Liu, Brooke Fisher and Horsley, J. Suzanne. 2007. The Government Communication Decision Wheel: Toward a Public Relations Model for the Public Sector',Journal of Public Relations Research,19:4,377 - 393. Publisher Routledge Informa Ltd Registered in England and Wales Online Publication Date: 28 August 2007. downloaded by: [Sarwoprasodjo, Sarwititi] On: 18 December 2008.

Nimmo, D. 1999. Komunikasi Politik; Komunikator, Pesan dan Media. Penerbit PT Remaja Rosdakarya. Bandung.

Servaes, Jan. 1999. Communication for Development. One World, Multiple Cultures. Hampton Press, Inc, New Jersey.

Pētersone, Baiba. 2007. "Integrated Approach to Development Communication: A Public Relations Framework for Social Changes" Paper presented at the annual meeting of the International Communication Association, TBA, San Francisco, CA, May 23, 2007 dipublikasi online 24 September 2008di download di http://www.allacademic.com/meta/p173080_index.html>,

Gastil, John. and Black, Laura. 2007. "Public Deliberation as the Organizing Principle of Political Communication Research" Paper presented at the annual meeting of the NCA 93rd Annual Convention, TBA, Chicago, IL, Nov 15, 2007 Online didownload 30 Oktober 2009 http://www.allacademic.com/meta/p183695 index.html

Public Deliberation as the Organizing Principle of Political Communication Research. didownload pada tanggal 9 Desember 2008 di http://www.allacademic.com/meta/p203427_index.html 
Ridout, T. N., Shah, D. V., Goldstein, K. M., \& Franz, M. M. 2007. Measuring Exposure to Campaign Advertising. didownload pada tanggal 9 Desember 2008 di http://www.allacademic.com/meta/p203427_index.html

Ridout, T. N., Shah, D. V., Goldstein, K. M., \& Franz, M. M. (2004). Evaluating measures of campaign advertising exposure on political learning. Political Behavior, 26(3), 201-225.

Roehrick, Katherine. and Bolls, Paul. 2006. "Take It Nice and Slow: The Effect of Political Advertising Strategy and Production Pacing on Attention and Memory" Paper presented at the annual meeting of the International Communication Association, Dresden International Congress Centre, Dresden, Germany, Jun 16, 2006 Online 〈PDF〉. 2008-12-09 <http://www.allacademic.com/meta/p92845_index.html

Sarwititi Sarwoprasodjo dkk. 2008. Kajian Pengembangan Sosialisasi Program Pembangunan PertanianTerhadap Media. PT Strategy Aliansi Komunika. Jakarta untuk Humas Deptan RI.

Shen, Feng. 2007. Measuring Issue and Image In Political Advertising: An Informational/Transformational Approach. Makalah disajikan pada pertemuan tahunan the Association for Education in Journalism and Mass Communication, The Renaissance, Washington, DC, Aug 08, 2007 didownload pada tanggal 9 Desember 2008 di http://www.allacademic.com/meta/p203427_index.html.

White, R A. 2004. Is 'Empowerment' the Answer?: Current Theory and Research on Development Communication . International Communication Gazette 2004; $66 ; \quad 7 \quad$ versi $\quad$ online di http://gaz.sagepub.com/cgi/content/abstract/66/1/7 didownload pada tanggal 28 November 2007

Habermas, J. (1989). The structural transformation of the public sphere. Cambridge: MIT Press 
